ARCHITECTURE OF MINOAN CRETE 
UNIVERSITY OF TEXAS PRESS

(n)

\section{ARCHITECTURE OF}

ARC

or

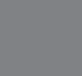




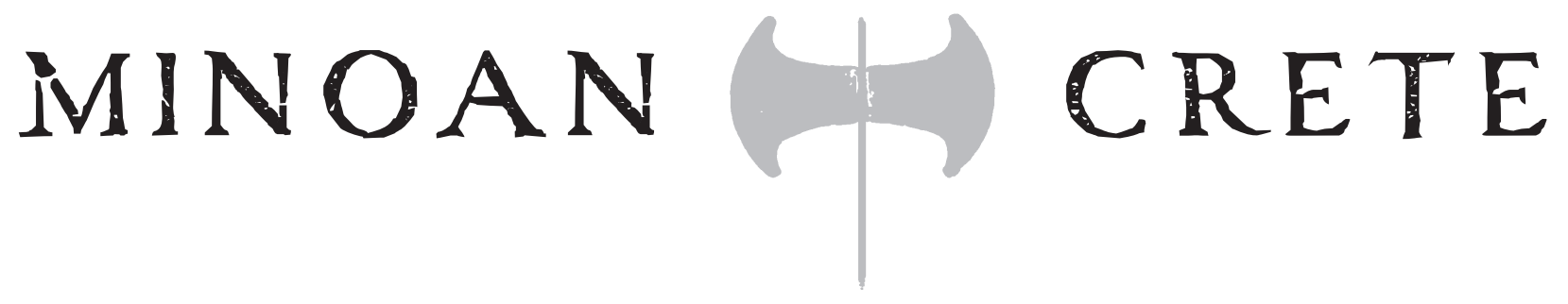

Constructing Identity in the Aegean Bronze Age

John C. McEnroe 


\section{To Catherine,}

For your patience and good humor as, year after year, we climbed up the wrong sides of the mountains.

Copyright (C) 2010 by the University of Texas Press All rights reserved

Printed in the United States of America

First edition, 2010

Requests for permission to reproduce material from this work should be sent to:

Permissions

University of Texas Press

P.O. Box 7819

Austin, TX 78713-7819

www.utexas.edu/utpress/about/bpermission.html

( The paper used in this book meets the minimum requirements of ANSI/NISO Z39.48-1992 (R1997)

(Permanence of Paper).

Library of Congress Cataloging-in-Publication Data

McEnroe, John C.

Architecture of Minoan Crete : constructing identity in the Aegean Bronze Age / John C. McEnroe.

p. $\mathrm{cm}$.

Includes bibliographical references and index.

ISBN 978-0-292-72 193-7 (cloth : alk. paper)

1. Architecture, Minoan. 2. Architecture and society-

Greece-Crete. I. Title. II. Title: Constructing identity in the Aegean Bronze Age.

NA267.M39 2010

$722 \cdot .61-\mathrm{dc} 22$

2009048479
This book has been supported by an endowment dedicated to classics and the ancient world and funded by the Areté Foundation; the Gladys Krieble Delmas Foundation; the Dougherty Foundation; the James R. Dougherty, Jr. Foundation; the Rachael and Ben Vaughan Foundation; and the National Endowment for the Humanities. 